\title{
UI KUALITAS UBI BEBERAPA KLON KENTANG HASIL PERSILANGAN UNTUK BAHAN BAKU KERIPIK
}

\section{QUALITY TESTING OF SEVERAL POTATO CLONES DERIVED FROM CROSSING FOR POTATO CHIPS}

\author{
Helmi Kurniawan ${ }^{1)}$ dan Tarkus Suganda ${ }^{2)}$ \\ ${ }^{1)}$ Balai Penelitian Tanaman Sayuran, Jl. Tangkuban Parahu No. 517 Lembang \\ ${ }^{2)}$ Fakultas Pertanian Universitas Padjadjaran, Jl. Raya Jatingor, Sumedang \\ Korespondensi : h_kurniawan1@yahoo.com
}

Diterima 27 September 2014/ Disetujui 12 Desember 2014

\begin{abstract}
ABSTRAK
Penelitian ini bertujuan menguji kualitas ubi beberapa klon kentang hasil persilangan sebagai bahan baku keripik. Penelitian dilakukan mulai Bulan Mei sampai Bulan Juli 2013 di Laboratorium Pasca Panen Balai Penelitian Tanaman Sayuran. Rancangan yang digunakan yaitu Rancangan Acak Lengkap (RAL) dengan tiga ulangan. Perlakuan yang diuji terdiri dari 6 klon hasil persilangan dan 3 varietas pembanding. Hasil penelitian menunjukkan bahwa perbedaan klon kentang memberikan pengaruh terhadap warna, rasa, kerenyahan, dan penampilan keripik yang dihasilkan dan klon kentang terbaik yang memenuhi persyaratan kualitas sebagai bahan baku keripik kentang adalah klon AR 08.
\end{abstract}

Kata kunci : Klon Kentang, Uji laboratorium, Kualitas, Keripik Kentang

\begin{abstract}
The objective of the research was to determine the quality of potato clones derived fromcrossing for potato chips. The research was conducted from May to July 2013 in Postharvest Laboratory of Research Institute for Vegetables, and arranged in a completely randomized design with tree replications. Quality test of 6 clones derived from crossing and 3 varieties control. The results showed that the difference in potato clones give effect to the color, taste, crispyness, and the appearance of the resulting chips and potato clones that best meet the quality requirements for potato chips was cloned AR 08.
\end{abstract}

Key words : Potato Clones, Laboratory Test, Quality, Potato Chips

\section{PENDAHULUAN}

Kentang (Solanum tuberosum L.) merupakan salah satu komoditas hortikultura yang penting di Indonesia dan sumber karbohidrat ke empat di dunia setelah gandum, beras dan jagung. Selain sebagai sumber karbohidrat, kentang juga memiliki kandungan nutrisi lain yang cukup tinggi, diantaranya protein, mineral dan 
asam amino, dan beberapa vitamin seperti vitamin A, vitamin B komplek serta vitamin C. Kandungan vitamin C pada kentang dapat mencukupi setengah kebutuhan per hari bagi orang dewasa dan lebih tinggi dibandingkan dengan padi dan gandum. Perbandingan protein terhadap karbohidrat yang terdapat di dalam ubi kentang lebih tinggi daripada biji serealia dan ubi lainnya. Kandungan asam amino ubi kentang juga seimbang, sehingga sangat baik bagi kesehatan (Kusmana dan Basuki 2004).

Sejalan dengan program ketahanan pangan dari pemerintah, kentang memiliki peluang untuk dijadikan alternatif diversifikasi pangan karena kandungan nutrisinya yang cukup tinggi. Dari tahun ke tahun kebutuhan kentang semakin meningkat seiring dengan peningkatan jumlah penduduk dan peningkatan pola hidup. Berbagai usaha pengembangan komoditas kentang telah ditempuh untuk meningkatkan produktivitas, termasuk di dalamnya adalah peningkatan luas lahan pertanaman kentang, perbaikan teknologi budidaya dan perakitan varietas unggul serta penyediaan benih berkualitas. Beberapa keuntungan dari kentang antara lain harga ubi di pasaran cukup tinggi dengan fluktuasi harga yang kecil serta ubi tidak mudah rusak, dan dapat dijadikan sebagai bahan baku industri kentang goreng (french-fries), keripik (chip), pati atau tepung kentang dan lain-lain, serta penggunaan kentang lebih dapat diterima oleh masyarakat luas dibandingkan dengan ubi kayu, ubi jalar atau jenis ubi lainnya.

Sebagai sumber karbohidrat, kentang mempunyai kelebihan dibandingkan dengan beras, dan kentang mempunyai potensi yang sangat besar sebagai pendamping beras. Di kota-kota besar terlihat adanya pergeseran pemanfaatan kentang sebagai sumber karbohidrat. Hal ini terlihat dengan semakin menjamurnya restoran cepat saji (fast food) yang ada umumnya menyediakan kentang goreng (french fries) sebagai salah satu kebutuhannya dan industri makanan olahan berbahan baku kentang. Bahkan di beberapa negara maju bisnis makanan ringan dari kentang terutama keripik kentang (potato chips) mempunyai pangsa pasar terbesar diantara produk makanan ringan lainnya. Di Indonesia, industri keripik kentang menunjukkan perkembangan yang cukup tajam pada tahun-tahun terakhir. Hal ini ditunjukkan dengan semakin meningkatnya permintaan kebutuhan bahan baku kentang untuk industri keripik kentang (Asgar et al., 2011).

Industri kentang membutuhkan bahan baku kentang jenis tertentu yang memenuhi persyaratan kualitas tertentu dan ini hanya dapat dipenuhi melalui hasil budidaya kentang yang baik, tidak hanya cara bertanamnya yang baik, tetapi juga melalui penggunaan benih yang berkualitas tinggi, serta penggunaan varietas kentang yang tepat untuk kebutuhan industri. Ada kecenderungan di kalangan petani kentang untuk menanam varietas baru yang unggul dan lebih tinggi daya hasilnya serta dapat dipergunakan dalam industri makanan. Untuk keperluan tersebut perlu dianalisis kandungan nutrisi dan diuji organoleptik keripik kentang (Asgar et al., 2011). Analisis kandungan nutrisi di laboratorium dilakukan untuk mengetahui berat jenis (Baedhowie dan Pranggonawati, 1983), gula reduksi dengan metode Luff Schorl (Baedhowie dan Pranggonawati, 1983), bahan kering dan kadar air dengan metode Gravimetri (Sudarmadji et al., 1997), kadar 
pati metode Luff Schorl (Baedhowie dan Pranggonawati, 1983).

Menurut Budiman (1999), standar yang diminta oleh industri keripik kentang sebagai bahan baku adalah specific gravity (SG) atau berat jenis (BJ) minimal 1,067 $\mathrm{g}$ $\mathrm{ml}^{-1}$ dan kadar bahan kering 16,7\%, sedangkan untuk kentang goreng mensyaratkan bentuk ubi memanjang dengan ukuran 170-284 g, specific gravity (SG) atau berat jenis (BJ) minimal 1,079 dan kadar bahan kering 20,5\%. Van Es dan Hartman (1987), menyatakan bahwa 2,5-3 $\mathrm{mg} \mathrm{gr}^{-1}$ dipandang sebagai batas gula reduksi yang jadikan standar kriteria untuk keripik kentang. Untuk keperluan uji organoleptik, kentang dicuci, ditiriskan lalu diiris dengan ketebalan 2-3 mm. Sampel keripik kentang diambil dari bagian tengah ubi sebanyak empat sampai enam irisan kentang per ubi. Irisan kentang yang telah ditiriskan, digoreng dalam minyak tertentu selama 3-4 menit pada suhu $180^{\circ} \mathrm{C}$ (Sinaga, 1992). Para panelis akan menilai keripik kentang secara organoleptik terhadap warna, rasa, kerenyahan, dan penampilan keripik kentang menurut metode Hedonik (Soekarto, 1985). Penilaian oleh panelis bersifat uji kesukaan dengan skala 1 sampai 5 ( 1 = sangat suka; 2 = suka; $3=$ biasa; 4 = tidak suka; 5 = sangat tidak suka).

Saat ini varietas yang berkembang di masyarakat petani dengan pertanaman mencapai $80-90 \%$ didominasi oleh varietas Granola, namun varietas ini tidak memenuhi syarat sebagai bahan baku keripik karena kadar bahan keringnya rendah (Wibowo 2006). Varietas Atlantik sampai saat ini merupakan satu-satunya varietas yang digunakan industri besar keripik kentang di Indonesia. Varietas Atlantik memiliki keunggulan dari segi rasa enak dan kualitas olahan namun kendala utama pengembangan varietas Atlantik adalah rentan terhadap penyakit hawar daun (Phytophthora infestans) dan penyakit bakteri layu (Ralstonia solanacearum). Kelemahan lainnya adalah daya hasilnya rendah dengan jumlah ubi pertanaman yang dihasilkan relatif sedikit (Kusmana, 2004). Upaya memperbaiki varietas yang telah berkembang senantiasa dilakukan untuk mendapatkan varietas unggul baru kentang yang sesuai dengan keinginan petani dan konsumen (Kusmana dan Sofiari, 2007).

Untuk memperbaiki kelemahan varietas Atlantik tersebut, pada tahun 2008 dilakukan upaya perbaikan dengan menyilangkan varietas Atlantik dengan varietas Repita. Varietas Repita yang telah dilepas oleh Balai Penelitian Tanaman Sayuran (Balitsa) tahun 2005, memiliki keunggulan berdaya hasil tinggi, dan memiliki ketahanan yang baik terhadap penyakit hawar daun, namun kurang disukai petani karena umur tanaman yang panjang, rasa kurang enak, mata ubi agak dalam (Kusmana dan Basuki, 2004). Hasil persilangan varietas Atlantik dengan varietas Repita diharapkan akan mendapatkan klon kentang baru dengan karakter berdaya hasil tinggi, toleran penyakit hawar daun, dan kualitas olahan yang cocok dijadikan sebagai bahan baku keripik kentang.

Klon-klon yang dicoba merupakan klon kentang hasil persilangan varietas Atlantik $x$ varietas Repita yang telah diseleksi terutama untuk karakter daya hasil, ketahanan terhadap penyakit hawar daun, kedalaman mata tunas, dan ukuran ubi relatif besar. Berdasarkan hal tersebut, maka diduga bahwa klon-klon yang diuji menunjukkan perbedaan kualitas fisik, kimia, dan karakter organoleptik sebagai 
bahan baku keripik kentang. Tujuan penelitian ini yaitu menguji kualitas ubi beberapa klon kentang hasil persilangan sebagai bahan baku keripik.

\section{BAHAN DAN METODE}

Penelitian dilakukan mulai Bulan Mei sampai Bulan Juli 2013 di Laboratorium Pasca Panen Balai Penelitian Tanaman Sayuran. Materi yang digunakan yaitu ubi dari 6 klon hasil persilangan antara varietas Atlantik dan varietas Repita. Sebagai pembanding disertakan ubi dari varietas Atlantik dan Repita sebagai tetua dan varietas Granola. Rancangan yang digunakan yaitu Rancangan Acak Lengkap (RAL) dengan tiga ulangan.

Jumlah bahan yang digunakan dalam pengujian sebanyak 2,5-3 kg per klon. Analisis kandungan nutrisi di laboratorium dilakukan untuk mengetahui berat jenis (Baedhowie dan Pranggonawati, 1983), gula reduksi dengan metode Luff Schorl (Baedhowie dan Pranggonawati, 1983), bahan kering dan kadar air dengan metode Gravimetri (Sudarmadji et al., 1997), kadar pati dengan metode Luff Schorl (Baedhowie dan Pranggonawati, 1983).

Untuk keperluan uji organoleptik, kentang dicuci, ditiriskan lalu diiris dengan ketebalan 2-3 mm. Sampel keripik kentang diambil dari bagian tengah ubi sebanyak empat sampai enam irisan kentang per ubi. Irisan kentang yang telah ditiriskan, digoreng dalam minyak tertentu selama 34 menit pada suhu $180^{\circ} \mathrm{C}$ (Sinaga, 1992). Panelis terdiri atas 30 orang yang menilai keripik kentang secara organoleptik terhadap warna, rasa, kerenyahan, dan penampilan menurut metode Hedonik (Soekarto, 1985). Skala nilai untuk tiap parameter sebagai berikut:

- Warna: 1 = kuning pucat, 2 = kuning merata, $3=$ kuning keemasan, $4=$ kuning kecoklatan, $5=$ coklat

- Rasa: 1= sangat suka, 2 = suka, 3 = biasa, 4 = tidak suka, $5=$ sangat tidak suka.

- Kerenyahan: 1 = sangat renyah, 2 = renyah, $3=$ biasa, $4=$ tidak menarik, $5=$ sangat tidak menarik.

- Penampilan: 1 = sangat menarik, 2 = menarik, 3 = biasa, 4 = tidak menarik, 5 = sangat tidak menarik

Data dianalisis dengan Analisis Sidik Ragam (ANOVA) dengan menggunakan program SPSS versi 16.0 dan uji lanjutan menggunakan LSD (uji beda nyata terkecil) pada taraf $5 \%$.

\section{PEMBAHASAN}

\section{Berat Jenis}

Hasil analisis terhadap karakteristik berat jenis dapat disajikan pada Tabel 1 . Pada Tabel 1 dapat dilihat bahwa berat jenis keenam klon hasil persilangan dan tiga varietas pembanding tidak berbeda nyata, nilainya berkisar antara 1,052-1,077 gr $\mathrm{ml}^{-1}$. Nilai berat jenis mempunyai korelasi dengan kandungan bahan padat, semakin tinggi kandungan bahan padat, maka semakin baik klon tersebut dijadikan bahan baku keripik (Basuki et al., 2005). Berat jenis ubi kentang merupakan salah satu syarat untuk menentukan kualitas olahan. Menurut Budiman (1999), berat jenis ubi kentang minimum untuk standar industri pengolahan keripik yaitu 1,067 gr $\mathrm{ml}^{-1}$. Menurut kriteria berat jenis ini, ada dua klon kentang yang memenuhi syarat sebagai bahan baku keripik kentang yaitu 
klon AR $05\left(1,082 \mathrm{gr} \mathrm{ml}^{-1}\right)$ dan klon AR $08 \quad\left(1,073 \mathrm{gr} \mathrm{ml}^{-1}\right)$.

Tabel 1. Karakteristik Berat Jenis, Kadar Bahan Kering, dan Kadar Air

\begin{tabular}{ccccccc}
\hline Klon atau Kultivar & $\begin{array}{c}\text { Berat Jenis } \\
\left(\mathrm{gr} \mathrm{ml}^{-1}\right)\end{array}$ & $\begin{array}{c}\text { Kadar Air } \\
(\%)\end{array}$ & $\begin{array}{c}\text { Kadar Bahan Kering } \\
\text { (\%) }\end{array}$ \\
\hline AR 04 & 1,060 & $\mathrm{a}$ & 83,59 & $\mathrm{~d}$ & 16,41 & $\mathrm{~b}$ \\
AR 05 & 1,082 & $\mathrm{a}$ & 81,60 & $\mathrm{c}$ & 18,40 & $\mathrm{c}$ \\
AR 06 & 1,065 & $\mathrm{a}$ & 84,98 & $\mathrm{e}$ & 15,02 & $\mathrm{a}$ \\
AR 07 & 1,055 & $\mathrm{a}$ & 80,78 & $\mathrm{~b}$ & 19,22 & $\mathrm{~d}$ \\
AR 08 & 1,073 & $\mathrm{a}$ & 80,03 & $\mathrm{a}$ & 19,97 & $\mathrm{e}$ \\
AR 09 & 1,052 & $\mathrm{a}$ & 83,27 & $\mathrm{~d}$ & 16,73 & $\mathrm{~b}$ \\
ATL & 1,072 & $\mathrm{a}$ & 79,37 & $\mathrm{a}$ & 20,63 & $\mathrm{e}$ \\
REPT & 1,077 & $\mathrm{a}$ & 82,14 & $\mathrm{c}$ & 17,86 & $\mathrm{c}$ \\
GRL & 1,053 & $\mathrm{a}$ & 84,78 & $\mathrm{e}$ & 15,22 & $\mathrm{a}$ \\
\hline
\end{tabular}

Keterangan : Angka yang diikuti huruf yang sama tidak berbeda nyata pada taraf beda nyata $5 \%$ menurut Uji Beda Nyata Terkecil.

\section{Kadar Air dan Kadar Bahan Kering}

Hasil analisis terhadap karakteristik kadar air dan kadar bahan kering ditunjukkan pada pada Tabel 1. Kadar air berkorelasi dengan kadar bahan kering, semakin tinggi kadar air, maka semakin rendah kadar bahan keringnya. Pada Tabel 1 dapat dilihat bahwa ada perbedaan nyata antar klon kentang untuk karakteristik kadar air dengan kisaran antara 79,37\%$84,98 \%$ dan untuk karakteristik kadar bahan kering dengan kisaran 15,02\%$20,63 \%$. Ubi kentang yang baik untuk bahan baku keripik kentang harus mempunyai kadar air yang rendah agar tidak hancur bila digoreng. Hal ini berhubungan dengan kadar bahan kering yang tinggi, dimana kandungan bahan kering yang tinggi merupakan suatu keharusan untuk memperoleh hasil pengolahan ubi yang baik. Menurut Asgar et al. (2011), industri pengolahan ubi kentang mengambil perhitungan terhadap kandungan bahan kering, gula reduksi, dan campuran nitrogen lain. Kentang yang mempunyai kadar bahan kering yang tinggi lebih disenangi dibandingkan dengan yang kadar bahan keringnya rendah.

Kadar bahan kering minimum untuk standar industri pengolahan keripik yaitu $16,7 \%$ akan memberikan tekstur renyah pada keripik (Budiman, 1999). Menurut kriteria kadar bahan kering, ada empat klon kentang yaitu klon AR 05 (18,40\%), klon AR 07 (19,22\%), klon AR 08 (19,97\%), dan klon AR $09(16,73 \%)$ yang memenuhi syarat untuk bahan baku keripik kentang.

\section{Kadar Pati}

Hasil analisis terhadap karakteristik kadar pati menunjukkan perbedaan nyata antar klon kentang dengan kisaran 4,40\%$11,84 \%$ (Tabel 2). Kandungan pati pada ubi kentang berhubungan dengan berat jenisnya, kentang dengan berat jenis yang tinggi pada umumnya memiliki kandungan pati yang juga tinggi. Menurut Asgar et al. (2011), kandar pati dipengaruhi oleh varietas, kultur teknis, umur panen, dan umur simpan ubi kentang. Kandungan pati dalam ubi kentang yang dipanen pada umur yang lebih tua akan lebih tinggi dari 
ubi yang dipanen pada umur lebih muda. Peningkatan umur panen akan memperpanjang proses fotosintesis sehingga menambah pula kandungan patinya. Selain dipengaruhi oleh umur panen dan lama penyimpanan, lokasi penanaman dan musim tanam juga berpengaruh terhadap kadar pati ubi kentang. Kandungan pati ubi kentang dapat ditingkatkan dengan penambahan unsur fosfat dan kalium pada masa pertumbuhan tanaman (Zhang Wen-kui, 2010).

Tabel 2. Karakteristik Kadar Pati, Kadar Gula Reduksi, dan TSS (Total Soluble Solid)

\begin{tabular}{crrrrrr}
\hline Klon atau Kultivar & $\begin{array}{c}\text { Kadar Pati } \\
(\%)\end{array}$ & \multicolumn{3}{c}{$\begin{array}{c}\text { Kadar Gula Reduksi } \\
\left(\mathrm{mg} \mathrm{gr}^{-1}\right)\end{array}$} & $\begin{array}{c}\text { TSS } \\
(\%)\end{array}$ \\
\hline AR 04 & 9,17 & $\mathrm{c}$ & 1,81 & $\mathrm{c}$ & 4,400 & $\mathrm{~cd}$ \\
AR 05 & 10,24 & $\mathrm{~d}$ & 0,14 & $\mathrm{a}$ & 4,350 & $\mathrm{bc}$ \\
AR 06 & 8,10 & $\mathrm{~b}$ & 0,21 & $\mathrm{ab}$ & 3,783 & $\mathrm{a}$ \\
AR 07 & 10,24 & $\mathrm{~d}$ & 0,19 & $\mathrm{ab}$ & 4,233 & $\mathrm{bc}$ \\
AR 08 & 11,47 & $\mathrm{e}$ & 0,17 & $\mathrm{ab}$ & 4,133 & $\mathrm{bc}$ \\
AR 09 & 7,99 & $\mathrm{~b}$ & 0,13 & $\mathrm{a}$ & 4,150 & $\mathrm{bc}$ \\
ATL & 11,84 & $\mathrm{f}$ & 0,18 & ab & 5,000 & $\mathrm{e}$ \\
REPT & 7,90 & $\mathrm{~b}$ & 0,26 & $\mathrm{~b}$ & 4,083 & $\mathrm{ab}$ \\
GRL & 4,40 & $\mathrm{a}$ & 3,54 & $\mathrm{~d}$ & 4,683 & $\mathrm{~d}$ \\
\hline
\end{tabular}

Keterangan : Angka yang diikuti huruf yang sama tidak berbeda nyata pada taraf beda nyata $5 \%$ menurut Uji Beda Nyata Terkecil.

Penurunan kadar pati juga dapat disebabkan adanya penyakit layu pada tanaman kentang yang menyebabkan busuk pada ubi kentang. Penyakit layu pada tanaman kentang disebabkan oleh beberapa patogen terutama bakteri Ralstonia solanacearum. Bakteri tersebut mampu mengoksidasi karbohidrat yang spesifik menjadi bentuk asam sehingga tidak terukur sebagai karbohidrat atau pati (Gunawan, 2006). Pada Tabel 2, kadar pati varietas Atlantik (varietas pembanding untuk kualitas olahan) menunjukkan nilai tertinggi yaitu $11,84 \%$. Kadar pati klonklon kentang hasil persilangan yang mendekati kadar pati varietas Atlantik yaitu klon AR 08 (11,47\%), klon AR 07 $(10,24 \%)$, dan klon AR 04 (10,24\%). Maka ketiga klon tersebut memiliki potensi sebagai bahan baku keripik kentang menurut kriteria kadar pati pada ubi kentang.

\section{Kadar Gula Reduksi}

Hasil analisis menunjukkan perbedaan nyata antar klon kentang untuk karakteristik kadar gula reduksi dengan kisaran antara 0,13-3,54 $\mathrm{mg} \mathrm{gr}^{-1}$ (Tabel 2). Berdasarkan perhitungan sidik ragam kelima klon kentang hasil persilangan yaitu klon AR $05\left(0,14 \mathrm{mg} \mathrm{gr}^{-1}\right)$, klon AR $06(0,21$ $\left.m g g^{-1}\right)$, klon AR $07\left(0,19 \mathrm{mg} \mathrm{gr}^{-1}\right)$, klon AR $08\left(0,17 \mathrm{mg} \mathrm{gr}^{-1}\right)$, dan klon AR $09(0,13 \mathrm{mg}$ $\mathrm{gr}^{-1}$ ) menunjukkan kadar gula reduksi yag tidak berbeda nyata dengan kadar gula reduksi varietas Atlantik (varietas pembanding untuk kualitas olahan) yaitu $0,18 \mathrm{mg} \mathrm{gr}^{-1}$.

Kandungan gula reduksi ubi kentang dipengaruhi oleh klon kentang dan umur panen. Umur panen yang tepat (umur panen 90 hari) akan menghasilkan ubi kentang dengan kandungan gula reduksi yang rendah (Asgar et al., 2011). Tingginya kadar gula reduksi berpengaruh pada 
kualitas hasil keripik kentang terutama penampilannya. Gula pereduksi yang berlebihan pada ubi kentang tidak dikehendaki karena mengakibatkan timbulnya warna pirang pada pengeringan dan penyimpanan setelah pengeringan. Sehingga mengurangi kualitas penampilan keripik kentang yang dihasilkan. Van Es dan Hartman (1987) menyatakan bahwa kandungan 2,5-3 $\mathrm{mg} \mathrm{gr}^{-1}$ berat basah harus dipandang sebagai batas gula reduksi yang direkomendasikan untuk keripik. Memandang kriteria tersebut, keenam klon kentang dapat diterima sebagai bahan baku keripik kentang.

\section{TSS (Total Soluble Solid)}

Hasil analisis dan uji statistik karakteristik TSS atau total padatan terlarut menunjukkan perbedaan nyata antar klon kentang dengan kisaran 3,783\%$5,000 \%$ (Tabel 2). Nilai TSS terendah ditunjukkan oleh klon AR 06 (3,783\%) dan tertinggi oleh varietas Atlantik (5,000\%). Total padatan terlarut adalah seluruh bahan padat yang ada dan larut dalam air di dalam ubi kentang. Bahan padat tersebut antara lain gula reduksi, sukrosa, asam-asam organik serta vitamin yang larut dalam air. Total zat padat akan mempengaruhi tekstur keripik keripik kentang. Padatan terlarut yang tinggi diduga disebabkan oleh proses pembentukan ubi kentang (Asgar et al., 2011).

\section{Organoleptik Warna}

Hasil uji organoleptik untuk warna keripik kentang ditampilkan pada Tabel 3. Analisis statistik menunjukkan perbedaan yang nyata antar klon kentang dengan nilai kisaran antara 1,67-3,80. Varietas Atlantik menunjukkan warna keripik kentang terbaik (nilai 1,67), tidak berbeda nyata dengan klon AR 08 (nilai 1,80), klon AR 07 (nilai 2,33), dan klon AR 09 (nilai 2,33). Kandungan gula reduksi sangat berpengaruh pada warna keripik kentang. Kandungan gula reduksi ketiga klon kentang tersebut tergolong rendah (Tabel 2). Namun kandungan gula reduksi pada ubi kentang bukan satu-satunya faktor penentu, sebab variabel lain yang berpengaruh terhadap warna keripik yaitu kultur teknis, lingkungan tanam, musim tanam dan faktor genetik dari klon atau varietas kentang. Van Es dan Hartman (1987) menambahkan bahwa umur panen dan umur penyimpanan ubi kentang juga berpengaruh terhadap warna keripik kentang.

Para panelis cenderung menentukan nilai terbaik untuk warna keripik kentang dengan kriteria warna kuning yang merata dan nilai terendah dengan kriteria warna keripik yang kecoklatan (browning). Warna coklat tersebut diduga terjadi karena proses pencoklatan antara gula-gula reduksi dengan gugus asam amino primer yang disebut dengan reaksi Maillard. Reaksi Maillard merupakan reaksi pencoklatan non enzimatis. Warna objektif keripik kentang dipengaruhi secara nyata oleh komposisi bahan baku yaitu warna awal bahan-bahan penyusunnya (Schmehling dan Arthur, 2006). Bagian permukaan luar dari keripik kentang berwarna coklat kekuningan merupakan hasil reaksi pencoklatan luar yang dipengaruhi oleh komposisi bahan, suhu, dan lama penggorengan. Unsur warna keripik menjadi parameter kualitas penilaian oleh para penelis yang mewakili konsumen pada umumnya, oleh karena itu sistem pengukuran yang akurat dan rinci merupakan cara dalam meningkatkan 
kontrol kualitas (Leon et al., 2005). Mendasar pada penilaian para panelis untuk organoleptik warna keripik kentang, klon kentang yang paling disukai yaitu klon AR 08, klon AR 07, dan klon AR 09.

\section{Rasa}

Analisis statistik pada uji organoleptik rasa menunjukkan adanya perbedaan nyata antar klon kentang oleh penilain para panelis dengan kisaran nilai antara 2,003,20 (Tabel 3). Penilaian terhadap rasa keripik kentang sangat subyektif namun secara umum para penelis menilai semua klon kentang yang diuji organoleptik mempunyai rasa yang disukai untuk keripik kentang.

Karakteristik rasa pada ubi kentang dipengaruhi oleh komposisi kandungan pati, gula dan solanin. Kandungan gula yang lebih tinggi pada ubi kentang muda (immature) menyebabkan rasa manis, sedangkan kandungan solanin tinggi pada ubi kentang menyebabkan bau langu (bitter) pada rasa keripik kentang.
Menurut Asgar et al. (2011), flavor dihasilkan dari kombinasi rasa, aroma dan tekstur. Flavor precursors yang disintesis oleh tanaman terdapat dalam bahan baku kentang terutama mengandung gula, asam amino, RNA dan lemak. Genotip tanaman, lingkungan penanaman, dan lingkungan penyimpanan mempengaruhi tingkat campuran kandungan ini dan enzim yang bereaksi dengan menghasilkan flavor. Identifikasi flavor adalah penting bagi pemulia dalam seleksi klon kentang untuk bahan baku keripik kentang.

\section{Kerenyahan}

Nilai rerata uji organoleptik untuk kerenyahan keripik berkisar antara 2,203,60 . Analisis statistik menunjukkan perbedaan nyata antara klon kentang hasil persilangan dengan varietas Repita dan varietas Granola (Tabel 3). Secara umum para panelis memberikan nilai kategori renyah untuk kerenyahan keripik kentang semua klon kentang yang diuji.

Tabel 3. Warna, Rasa, Kerenyahan, dan Penampilan Keripik Kentang

\begin{tabular}{clrlrrrrr}
\hline Klon atau Varietas & Warna & \multicolumn{1}{c}{ Rasa } & \multicolumn{3}{c}{ Kerenyahan } & \multicolumn{2}{c}{ Penampilan } \\
\hline AR 04 & 3,27 & $\mathrm{~d}$ & 2,67 & $\mathrm{ab}$ & 2,20 & $\mathrm{a}$ & 3,60 & $\mathrm{~cd}$ \\
AR 05 & 2,73 & $\mathrm{bc}$ & 2,40 & $\mathrm{ab}$ & 2,27 & $\mathrm{a}$ & 2,67 & $\mathrm{abc}$ \\
AR 06 & 2,53 & $\mathrm{bc}$ & 2,60 & $\mathrm{ab}$ & 2,20 & $\mathrm{a}$ & 2,67 & $\mathrm{abc}$ \\
AR 07 & 2,33 & $\mathrm{ab}$ & 2,07 & $\mathrm{a}$ & 2,33 & $\mathrm{a}$ & 2,87 & $\mathrm{abc}$ \\
AR 08 & 1,80 & $\mathrm{a}$ & 2,00 & $\mathrm{a}$ & 2,20 & $\mathrm{a}$ & 2,33 & $\mathrm{ab}$ \\
AR 09 & 2,33 & $\mathrm{ab}$ & 2,80 & $\mathrm{ab}$ & 2,20 & $\mathrm{a}$ & 2,67 & $\mathrm{abc}$ \\
ATLANTIK & 1,67 & $\mathrm{a}$ & 2,00 & $\mathrm{a}$ & 2,20 & $\mathrm{a}$ & 2,13 & $\mathrm{a}$ \\
REPITA & 2,87 & $\mathrm{bc}$ & 3,20 & $\mathrm{~b}$ & 3,60 & $\mathrm{~b}$ & 3,27 & $\mathrm{bcd}$ \\
GRANOLA & 3,80 & $\mathrm{~d}$ & 2,73 & $\mathrm{ab}$ & 3,47 & $\mathrm{~b}$ & 3,87 & $\mathrm{~d}$ \\
\hline
\end{tabular}

Keterangan : Angka yang diikuti huruf yang sama tidak berbeda nyata pada taraf beda nyata $5 \%$ menurut Uji Beda Nyata Terkecil.

Kerenyahan keripik kentang sulit untuk diukur sebab keripik cenderung menjadi lunak beberapa saat setelah proses penggorengan. Hal ini mungkin disebabkan oleh ketidaksempurnaan dalam proses penggorengan keripik kentang. Kerenyahan atau tekstur keripik kentang dipengaruhi oleh komposisi kimia ubi 
kentang. Abbot et al. (2005) menyatakan bahwa kerenyahan disebabkan oleh perbedaan kandungan pati dan pektin yang mempengaruhi tektur. Sedangkan menurut Asgar et al. (2011) bahwa penambahan umur panen dapat menambah kerenyahan keripik kentang, dimana semakin lama umum panen, maka kerenyahan semakin meningkat.

\section{Penampilan}

Penampilan yang dimaksud adalah kehalusan permukaan dan hal-hal lain yang terlihat di permukaan keripik kentang tanpa memperhatikan warna dan ukurannya. Kandungan air sangat berpengaruuh terhadap penampilan keripik kentang (Asgar et al., 2011). Berdasarkan hasil analisis uji organoleptik terhadap penampilan keripik kentang menunjukkan perbedaan nyata antar klon kentang yang diujikan dengan kisaran nilai antara 2,13-3,87 (Tabel 3). Klon terbaik dengan nilai penampilan antara 1-3 menurut para panelis yaitu klon AR 05 (nilai 2,67), klon AR 06 (nilai 2,67), klon $A R$ 07 (nilai 2,87), klon AR 08 (nilai 2,33), dan klon AR 09 (nilai 2,67). Penampilan klonklon tersebut tidak berbeda nyata dengan penampilan varietas Atlantik (nilai 2,13 ).

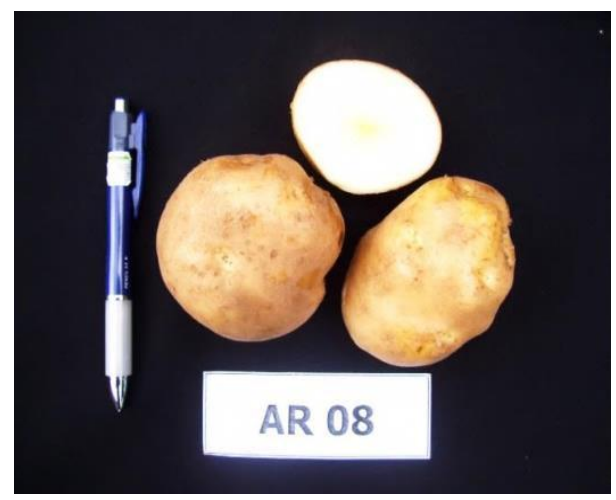

\section{Klon Kentang Terpilih}

Untuk penentuan keripik yang terpilih dari klon-klon kentang disajikan pada Tabel 4. Menurut penilaian para panelis dalam uji organoleptik keripik kentang dengan kriteria warna, rasa, kerenyahan dan penampilan keripik kentang menunjukkan bahwa produk keripik kentang dengan bahan baku kentang klon AR 08 merupakan produk keripik kentang yang terbaik karena mempunyai nilai rerata terkecil yang banyak disukai oleh para panelis. Penilaian oleh panelis bersifat uji kesukaan dengan skala 1 sampai 5 (1=sangat suka; 2=suka; 3=biasa; 4=tidak suka; 5=sangat tidak suka). Hasil penilaian organoleptik para panelis terhadap klon AR 08 tidak jauh berbeda dengan penilaian terhadap varietas Atlantik (varietas pembanding untuk kualitas olahan). Hal ini disebabkan oleh kandungan nutrisi klon AR 08 yang disajikan pada Tabel 1 dan Tabel 2, seperti berat jenis $\left(1,073 \mathrm{gr} \mathrm{ml}^{-1}\right)$, kadar bahan kering $(19,97 \%)$, kadar pati $(11,47 \%)$, dan

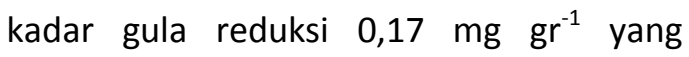
memenuhi syarat untuk bahan baku keripik kentang.

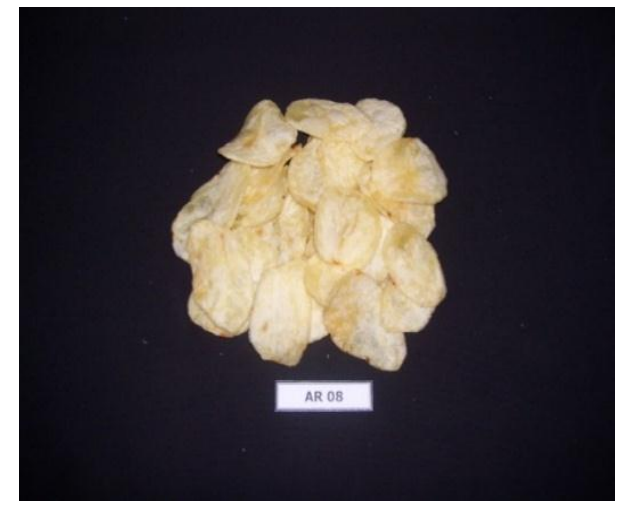

Gambar 1. AR 08 Klon Kentang Terpilih untuk Bahan Baku Keripik 
Tabel 4. Penentuan Keripik Terpilih dari Klon-klon Kentang

\begin{tabular}{|c|c|c|c|c|c|}
\hline \multirow{2}{*}{ Klon atau Varietas } & \multicolumn{4}{|c|}{ Respon Organoleptik } & \multirow{2}{*}{ Total } \\
\hline & Warna & Rasa & Kerenyahan & Penampilan & \\
\hline AR 04 & 3,27 & 2,67 & 2,20 & 3,60 & 11,74 \\
\hline AR 05 & 2,73 & 2,40 & 2,27 & 2,67 & 10,07 \\
\hline AR 06 & 2,53 & 2,60 & 2,20 & 2,67 & 10,00 \\
\hline AR 07 & 2,33 & 2,07 & 2,33 & 2,87 & 9,60 \\
\hline AR 08 & 1,80 & 2,00 & 2,20 & 2,33 & 8,33 \\
\hline AR 09 & 2,33 & 2,80 & 2,20 & 2,67 & 10,00 \\
\hline ATLANTIK & 1,67 & 2,00 & 2,20 & 2,13 & 8,00 \\
\hline REPITA & 2,87 & 3,20 & 3,60 & 3,27 & 12,94 \\
\hline GRANOLA & 3,80 & 2,73 & 3,47 & 3,87 & 13,87 \\
\hline
\end{tabular}

\section{SIMPULAN}

1. Perbedaan klon kentang memberikan pengaruh terhadap warna, rasa, kerenyahan, dan penampilan keripik yang dihasilkan.

2. Klon kentang terbaik yang memenuhi persyaratan kualitas sebagai bahan baku keripik kentang adalah klon AR 08.

\section{DAFTAR PUSTAKA}

Abbot, Judih A. dan F. Roger Harker. 2005. Texture. The Horticulture and Food Research Instead Of New Zaeland.

Asgar, A., S.T. Rahayu, Kusmana, dan E. Sofiari. 2011. Uji Kualitas Umbi Beberapa Klon Kentang untuk Keripik. J.Hort. 21(1): 51-59.

Baedhowie, M. dan S. Pranggonawati. 1983. Petunjuk Praktek Pengawasan Mutu Hasil Pertanian. Departemen Pendidikan dan Kebudayaan, Direktorat Pendidikan Menengah Kejuruan. $129 \mathrm{HIm}$.

Basuki, R.S., Kusmana, dan A. Dimyati. 2005. Analisis Daya Hasil, Mutu, dan
Respons Pengguna terhadap Klon 380584, TS-2, FBA-4, I-1085, dan MF-II sebagai Bahan Baku Keripik Kentang. J. Hort. 15(3):60-70.

Budiman, A. 1999. Kebutuhan bahan baku untuk produksi olahan kentang. PT. Indofood Frito-Lay Corp. Makalah Seminar Kebutuhan dan Peluang untuk Pengembangan PHAT Kentang. Bogor Maret 1999.

Gunawan, O.S. 2006. Virulensi dan Ralstonia solanacearum pada Pertanaman Kentang di Kecamatan Pangalengan, Kabupaten Bandung, Jawa Barat. J. Hort. 16(3):211-218.

Kusmana dan R.S. Basuki. 2004. Produksi dan Mutu Kentang (Solanum tuberosum L.) dan Kesesuaiannya sebagai Bahan Baku Kentang Goreng dan Keripik. J. Hort. 14 (4) : 246-252.

dan E. Sofiari. 2007. Seleksi Galur Kentang dari Progeni Hasil Persilangan. Bul. Plasma Nutfah. 13(2):56-61.

Leon, Katherin, D. Mery, dan F. Pedreschi. 2005. Color Measurements in $L^{*} a^{*} b^{*}$ Unit from RGB Digital Unit. Universidad 
de Santiago de Chile (USACH), Santiago.

Schmehling dan C. Arthur. 2006. Communicating Food Color Effectively with Physical Color Standards in ACS SYMPOSIUM SERIES 983 Color Quality of Fresh and Processed Foods.

Sinaga, R.M. 1992. Pengaruh Jenis Kemasan dan Minyak Goreng terhadap Mutu Keripik Kentang (Solanum tuberosum L.). Bul. Penel. Hort. XXII (1):26-38.

Soekarto, S.T. 1985. Penilaian Organoleptik. Bhatara Karya Aksara, Yogyakarta. $268 \mathrm{HIm}$.

Sudarmadji, S., H. Bambang, dan Suhardi. 1997. Analisis Bahan Makanan dan
Pertanian. Penerbit Liberty: Yogyakarta. $160 \mathrm{HIm}$.

Van Es, A. dan K.J. Hartman. 1987. Structure and Chemical Composition of the Potato in Storage of Potato, in Rastovski, A. Van Es. (Eds.) Pudoc Wageningen. $7 \mathrm{p}$.

Wibowo. 2006. Peningkatan Kualitas Keripik Kentang Varietas Granola dengan Pengolahan Sederhana. J. Akta Agronesia. 9(2): 102-109.

Zhang Wen-kui. 2010. Effect of Fertilization on Hight Yield Potato Qingshu 2. Science and Technology of Oinghai Agriculture and Forestry, Abstract. En. cnki.com.cn/Article_en/CJFDTOTAL.QH NK20702032.HTM [07-12-2010). 